\title{
Microbial iron reduction and methane oxidation in subsurface sediments of the Arabian Sea
}

\author{
Christabelle E.G. Fernandes, Maria Judith B.D. Gonsalves*, Delcy R. Nazareth, \\ Lubbnaz Nagarchi, Sam Kamaleson A. \\ Aqua-Geomicrobiology Laboratory, National Institute of Oceanography, Council of \\ Scientific and Industrial Research, Dona Paula, Goa, India. \\ ${ }^{*}$ Corresponding author \\ E-mail address: mjudith@nio.org \\ Telephone: 91-0832-2450624
}

\begin{abstract}
Arabian Sea is one of the most productive regions of the world's ocean with seasonal upwelling and a characteristic oxygen minimum zone. It receives a continuous input of windborne iron-rich dust which possibly stimulates phytoplankton productivity. A sediment core from this area, which is on the western continental margin of India in the Kerala-Konkan basin was studied from the surface to 63 meters below seafloor, to establish the co-occurrence of microbial iron reducing activity and methane oxidation. Total bacterial abundance (TC), viable aerobic counts accounting for aerobic and facultative anaerobes (TVCa), viable anaerobic counts (TVCan), methane, sulfate, ferrous [Fe(II], hydroxylamine extractable iron and $\mathrm{HCl}$ extractable iron concentrations were measured. Average TC was $52.6 \pm 29.8 \times 10^{5}$ cells $\mathrm{g}^{-1}$ sediment while TVCa and TVCan were an order less. Methane and sulphate concentrations were $1.3 \mathrm{ppm}$ and $23.2 \mathrm{mM}$, respectively. Average $\mathrm{Fe}(\mathrm{II})$ concentration, hydroxylamine and $\mathrm{HCl}$ extractable Fe was $0.32 \pm 0.26,0.86 \pm 1.44$ and $1.90 \pm 2.47 \mathrm{mmol} \mathrm{g}^{-1}$ sediment, respectively. Interestingly, $\mathrm{Fe}(\mathrm{II})$ significantly correlated with TVCan $(r=0.66, p \leq 0.001)$.

In the experimental tubes, the build-up of Fe (II) was accompanied by the disappearance of methane. Average methane concentration and Fe (II) concentration in the experimental sediment slurries was $0.56 \pm 0.76 \mathrm{ppb}$ and $0.50 \pm 0.27 \mathrm{mmol} \mathrm{g}^{-1}$ sediment respectively. The microcosm experiment showed that $\mathrm{Fe}$ (II) determined was significantly higher (ANOVA, $F=6.74, p \leq 0.014$ ) after 5 days of incubation, thus implying microbial iron reducing activity. A strong negative linear correlation $(p \leq 0.001)$ of methane concentration with Fe (II) suggests that increasing activity of microbial iron reduction
\end{abstract}


caused suppression in methane production. This is also indicative of the co-occurrence of iron reduction and methane oxidation in these sediments.

\section{Key words}

Bacteria; iron; methane; Kerala-Konkan basin; Environmental; Abiotic

\section{Introduction}

The deep sub-surface sediments deposited millions of years ago comprises of a vast sedimentary ecosystem of microbial population consisting of diverse genomic and physiological repertoire (D'Hondt et al., 2004). The global subseafloor sedimentary microbial abundance has been estimated to be $2.9 \times 10^{29}$ cells (Kallmeyer et al. 2012). Estimates of the microbial abundance obtained from cores extending $>1000$ meters below the marine subsurface (mbsf) through dedicated deep-sea drilling expeditions, have revealed $>10^{5}$ microbial cells $/ \mathrm{cm}^{3}$ (Teske 2013). Even ultraoligotrophic regions such as the South Pacific Gyre and the North Pacific Gyre have cell abundance of $\sim 10^{3}$ microbial cells $/ \mathrm{cm}^{3}$ (D'Hondt, et al., 2009, Kallmeyer et al., 2012). Evidence is found for living microbial cells in the form of intact prokaryotic cells with an appreciable percentage of dividing cells in 1626 mbsf sediments on the Newfoundland Margin that are $111 \mathrm{My}$ old and at $60^{\circ}$ to $100^{\circ} \mathrm{C}$ (Roussel et al., 2008). Numerous studies have provided glimpses of the existence of genetically and metabolically diverse microbial communities consisting of archaea and bacteria which play an important role in global biogeochemical processes. Attempts have also been made, to probe the link between indigenous microbial communities and biogeochemical processes, sediment geochemistry, and past geological events in sub-seafloor environments (Inagaki et al., 2003, 2006; Parkes et al., 2005; Biddle et al., 2006).

Across the world's ocean, the conditions for deep biosphere vary extremely. This is due to geological properties such as age and the type of sediment, sedimentation rate, organic matter availability, temperature, hydrostatic pressure, etc. (Whitman et al., 1998). The bacterial communities herein are shaped by a range of microhabitat properties including pore size, availability of carbon and mineral substrates (Inagaki et al., 2002, 2003; Strong et al., 2004; Carson et al., 2009). However, in the deep sea subsurface, there is a severe limitation of nutrients and energy in the form of microbially degradable organic carbon and electron acceptor/donor, respectively (Jorgensen and Boetius, 2007). To cope up with this condition, organisms may obtain the necessary 

such as anaerobic oxidation of methane (AOM). Nearly $90 \%$ of the oceanic methane produced is recycled in anaerobic marine sediments through methane oxidation (Reeburgh et al., 1993). In marine environments, microbially-mediated AOM could possibly act as a sink for the large amounts of methane produced in marine sediments by reducing the release of methane by $5-20 \%$ of the global methane flux (Reeburgh, 1996, 2007; Valentine et al., 2000), thus acting as gatekeepers of these sea-floor reservoirs (Joye, 2012). As an electron donor, microbially mediated methane oxidation occurs with various electron acceptors (Orcutt et al., 2011). Sulfate reduction mediated $\mathrm{AOM}$ has been suggested in a variety of marine environments, as sulfate is the dominant electron acceptor for methane oxidation (Iversen and Jorgensen, 1985; Boetius et al., 2000; Treude et al., 2003; Knittel and Boetius, 2009). AOM has also been shown to be coupled to nitrate in freshwater environments (Deutzmann and Schink, 2011; Katrin and Thamdrup, 2014). Besides, recent preliminary evidence through laboratory experiments have demonstrated that microbially-mediated AOM may also be coupled to the reduction of highly reactive manganese/iron phases (Beal et al., 2009; Segarra et al., 2013). The availability of ferric iron [Fe (III)] can be a major factor controlling the amount of methane produced (Bond and Lovley, 2002; Riedinger et al., 2014).

The Arabian Sea is one of the most biologically productive regions of the world's ocean having a characteristic seasonal upwelling and an oxygen minimum zone (Wyrtki, 1971; Madhupratap et al., 1996; Naidu, 1998). The seasonal upwelling in return has been reported to have prolonged and distinct effect on biological production and sedimentation (Madhupratap et al., 1996). Another important feature unique to the Arabian Sea is that it is open to the ocean only from the Southern side since it is surrounded on three sides by arid land. Due to the proximity of arid land, Arabian Sea receives continuous input of windborne iron-rich dust which possibly stimulates phytoplankton productivity (Measures and Vink, 1999; Witter et al., 2000). Further, due to the ability of iron to oxidize and reduce easily, iron has been known to drive many reactions involving cycles of carbon, nitrogen, phosphorus, sulphur, etc. The high primary production in the Arabian Sea water column results in accumulation of organic carbon and subsequently high (anaerobic) respiration in sediments leading to accumulation of $\mathrm{H}_{2} \mathrm{~S}$ and $\mathrm{CH}_{4}$ in the porewaters (Bruchert et al., 2006). This is of vital interest since it may act as a potential source of $\mathrm{CH}_{4}$ input to the overlying water column. 
Thus, Arabian Sea presents a unique region which is uncommon to other parts of the world. To our knowledge, there is some information on the geology of subsurface seafloor sediments of Arabian Sea (Schnetger et al., 2000; Pattan et al., 2012), whereas, information on the microbiological aspects is very scarce. In this study, we evaluated the importance of sedimentary ferric minerals in the microbially-mediated oxidation of methane in Arabian Sea marine sediments. To understand whether the process of iron reduction might regulate methane cycling and further examine the potential coupling between AOM and iron reduction, we measured methane oxidation and iron reducing activity through short-term incubation of sediment slurries.

\section{Materials and Methods}

\subsection{Sampling site}

The sampling site NGHP-01-01 (National Gas Hydrate Program-01-01) was on the western continental margin of India in the Kerala-Konkan basin of the Arabian Sea. The investigated piston core - NGHP-01-1A was cored to $290 \mathrm{mbsf}\left(15^{\circ} 18.366^{\prime} \mathrm{N}, 70^{\circ}\right.$ $54.192^{\prime} \mathrm{E}$ ) and was retrieved from water depth of $\sim 2663 \mathrm{~m}$ during D/V JOIDES Resolution NGHP 01 expedition in May 2006. The sedimentary sequence in the Hole NGHP-01-1A was divided into four major lithologic units (Units I to IV) based on visual description, biogenic and terrigenous composition, trends in logging and physical properties data (Collett et al., 2007). Sediment samples up to a depth of $63 \mathrm{mbsf}$ from litostratigraphic unit I (LSI) were considered for the present study. LSI was composed of $80-100 \%$ clay followed by $5-20 \%$ silt and consisted of foraminifera-bearing nannofossil ooze of Quaternary age (Collett et al., 2007). Further, gas headspace analyses of these samples did not indicate detectable levels of hydrogen sulphide $\left(\mathrm{H}_{2} \mathrm{~S}, 20 \mathrm{ppmv}\right)$, methane (15ppmv) or other hydrocarbon gas. However, carbon dioxide $\left(\mathrm{CO}_{2}\right)$ concentrations expressed as equivalent concentration of gas volume to sediment volume ranged between 0.2 and $0.7 \mathrm{mM}$ porewater (Collett et al., 2007).

\subsection{Sample processing and analysis}

\subsubsection{Enumeration of bacterial abundance}

Contamination assays and aseptic conditions for microbiological samples were maintained during sampling (Smith et al., 2000). Sediment cores were sectioned at various depths. Potentially contaminated sediment was removed with a sterile scalpel. Sterile 3 cubic $\mathrm{cm}$ plastic syringes were used to sub-sample. Sub-samples were diluted 
using $0.2 \mu \mathrm{M}$ filtered and autoclaved seawater in the ratio 1:10 (wet wt. vol ${ }^{-1}$ ). Bacterial parameters such as total bacterial abundance (TC), viable aerobic counts (TVCa) and viable anaerobic counts (TVCan) were estimated.

Briefly, for TC, bacterial cells were stained using the method described by Deming and Colwell (1982). A 2.5\% final concentration of pre-filtered formaldehyde was used to fix 5 $\mathrm{ml}$ aliquot of sediment slurry. One $\mathrm{ml}$ of the fixed sample was stained with acridine orange (AO; Sigma) at a concentration of $0.01 \%\left(\mathrm{wt}^{\mathrm{v}} \mathrm{vol}^{-1}\right)$ for $5 \mathrm{~min}$ and filtered onto a $0.22 \mu \mathrm{m}$ Nuclepore black polycarbonate filter paper (Millipore). The filter papers were examined by epifluorescence microscopy (Nikon 50i), and bacterial counts were enumerated according to Hobbie et al. (1977). The detection limit was $1.79 \times 10^{5}$ cells $\mathrm{g}^{-}$ ${ }^{1}$ sediment and was calculated according to Kallmeyer et al. (2008).

To enumerate cells responsive to nutrient enrichment under aerobic conditions (TVCa) as well as the facultative anaerobes, yeast extract $(0.01 \%$ final concentration) and an antibiotic cocktail was added to $5 \mathrm{ml}$ of sediment slurry. Antibiotic cocktail comprised of nalixidic acid, piromedic acid and pipemedic acid and was used to inhibit DNA synthesis and cell division (Kogure et al. 1979; Joux and LeBaron, 1997). Slurry was incubated for a period of $7 \mathrm{~h}$ (prestandardized), subsequently fixed, stained and counted as described by Deming and Colwell (1982) and Hobbie et al. (1977). Similarly, to enumerate responsive cells under anaerobic conditions (TVCan), in addition to yeast extract and antibiotic cocktail, a reducing agent, $\mathrm{Na}_{2} \mathrm{~S} .9 \mathrm{H}_{2} \mathrm{O}(0.125 \%$ final concentration) was added to induce anaerobic conditions (Loka Bharathi et al., 1999, Kerkar and Loka Bharathi, 2011). Only elongated and enlarged cells with clearly visible invagination were counted as viable cells (Roszak and Colwell, 1987).

\subsubsection{Geochemical Parameters}

Sediment cores were sectioned on board at various depths, placed into sample bags, purged with nitrogen gas and frozen at $-20^{\circ} \mathrm{C}$.

\subsubsection{Estimation of methane concentrations}

Methane concentrations were measured using the headspace method (Gonsalves et al., 2011). The pre-weighed sample vials containing sediments were analyzed for methane concentration using a gas chromatograph (SHIMADZU 2010, Japan) in which a flame ionization detector was used, nitrogen gas was the carrier gas with a flow rate of $9.0 \mathrm{ml}$ 
$\min ^{-1}$. The column temperature was $60^{\circ} \mathrm{C}$, while both injector and detector temperatures were set at $100^{\circ} \mathrm{C}$ (Nakibuuka et al., 2012). All the above instrument parameters were kept constant throughout the whole study.

\subsubsection{Estimation of sulfate concentrations}

Sulfate $\left(\mathrm{SO}_{4}{ }^{2-}\right)$ concentrations were measured by turbidometry (Clesceri et al., 1998). Briefly, sediment samples were acidified $(\mathrm{pH} 1)$ with $4 \mathrm{~N} \mathrm{HCl}$. Conditioning solution, containing $\mathrm{NaCl}$, ethanol, $\mathrm{HCl}$ and glycerine was subsequently added. Finally, barium chloride at a final concentration of $30 \%$ was added. The amount of sulfate present in the sample was measured at $365 \mathrm{~nm}$ (Jasco V-650, Japan), as the concentration of sulphate is directly proportional to the precipitate formed as barium sulfate.

\subsubsection{Estimation of sedimentary iron concentrations}

Frozen sediment samples $\left(-20^{\circ} \mathrm{C}\right)$ were used to measure different fractions of sedimentary iron concentrations consisting of ferrozine extractable ferrous iron [Fe(II)], hydroxylamine extractable ferrous iron $(\mathrm{Hy}-\mathrm{Fe})$ and $1 \mathrm{~N} \mathrm{HCl}$ extractable ferrous iron $(\mathrm{HCl}-$ Fe) (Lovley and Phillips 1986, 1987). Thawed wet sediment was extracted with ferrozine in 50mM N-2-hydroxyethylpiperazine-N9-2- ethanesulfonic acid (HEPES) buffer ( $\mathrm{pH} 7$ ) to represent adsorbed ferrous iron. Similarly, extraction with hydroxylamine represented as $\mathrm{HY}-\mathrm{Fe}$ and with $1 \mathrm{~N} \mathrm{HCl}$ represented as $\mathrm{HCl}-\mathrm{Fe}$ was carried out for 24h, before adding the buffered ferrozine solution. HY-Fe represented the $\mathrm{Fe}$ fractions present as reactive/bioavailable ferric iron and $\mathrm{HCl}-\mathrm{Fe}$ represented the reactive solid phase $\mathrm{Fe}$. Ferrozine is essentially used as an indicator as it is specific to $\mathrm{Fe}$ (II) and complexes with $\mathrm{Fe}(\mathrm{II})$ to form a magenta ferrozine-ferrous iron complex [Fe(II)(FZ)3] with a maximum absorbance at $562 \mathrm{~nm}$ (Stookey, 1970). The amount of soluble $\mathrm{Fe}(\mathrm{II})$ was then quantified by measuring the absorbance at $562 \mathrm{~nm}$ using a spectrophotometer (Jasco V650 , Japan). Calibration curve was obtained using $\mathrm{FeSO}_{4} \cdot 7 \mathrm{H}_{2} \mathrm{O}$ in $0.1 \mathrm{~N} \mathrm{HCl}$ as the standard.

\subsection{Iron reduction and methane oxidation by indigenous microflora in microcosms containing Kerala-Konkan basin sediments}

Briefly, sediment slurry was prepared by adding one gram of sediment to $10 \mathrm{ml}$ of modified ferrozine medium in pre-weighed $15 \mathrm{ml}$ gas chromatography vials which were flushed with oxygen free nitrogen gas (Fernandes et al., 2011). The ferrozine medium 
contained $20 \mathrm{mM}$ HEPES and $350 \mathrm{mM}$ ferrozine in artificial seawater $(\mathrm{pH} 7.8 \pm 0.2)$. Artificial seawater consisted of $24.7 \mathrm{~g} \mathrm{NaCl}, 6.3 \mathrm{~g} \mathrm{MgSO}_{4} .7 \mathrm{H}_{2} \mathrm{O}, 4.6 \mathrm{~g} \mathrm{MgCl}_{2} .6 \mathrm{H}_{2} \mathrm{O}, 1.0 \mathrm{~g}$ $\mathrm{CaCl}_{2}, 0.7 \mathrm{~g} \mathrm{KCl}$ and $0.2 \mathrm{~g} \mathrm{NaHCO}_{3}$ (Atlas, 2004). Interference by sulfate reduction was inhibited by the addition of $20 \mathrm{mM}$ sodium molybdate (Coates et al., 1996, Nielsen et al., 2002). The vials were incubated without shaking under dark and anaerobic conditions at $4 \pm 0.2^{\circ} \mathrm{C}$. Control sets were prepared using a final concentration of $20 \mathrm{mM}$ sodium azide. Methane and $\mathrm{Fe}$ (II) concentrations were measured on 0-day and 5-day in the experimental vials. Methane concentration in the headspace was measured as previously mentioned in section 2.2.2.1. This measurement was immediately followed by the quantification of $\mathrm{Fe}(\mathrm{II})$ as mentioned before in section 2.2.2.3.

\subsection{Statistical analyses}

Bacterial parameters comprising of TC, TVCa and TVCan were log transformed for statistical analysis. Interrelationships between bacterial and geochemical parameters in the sediment were analyzed using Pearson's rank correlation. Bonferroni correction was incorporated to make an adjustment to the $p$ values. This correction is usually made when multiple comparisons are made on a single dataset so as to reduce the number of false positives (Legendre and Legendre, 1998). Bonferroni correction was used to set the significance $p$ cut-off value at $\alpha^{\prime}=\alpha / k$, where $k=$ number of treatments, $\alpha=$ uncorrected significance level, $\alpha^{\prime}=$ corrected significance level. Here, $k=12, \alpha=0.05, \alpha^{\prime}=0.004$.

Data for statistical analysis for the microcosm experiment consisted of two parameters i.e. methane and $\mathrm{Fe}(\mathrm{II})$ concentration. Initially, one-way analysis of variance (ANOVA) was performed on data obtained on 0 -day and $5^{\text {th }}$ day to check whether there was significant variation between initial and final dataset. Pearson rank correlation analysis was done to determine the interrelationship between methane and $\mathrm{Fe}(\mathrm{II})$ concentration in the microcosms. All statistical analysis was done using Statistica version 10.0. (StatSoft, Tulsa, Oklahoma, USA).

\section{Results}

\subsection{Distribution of bacterial parameters}

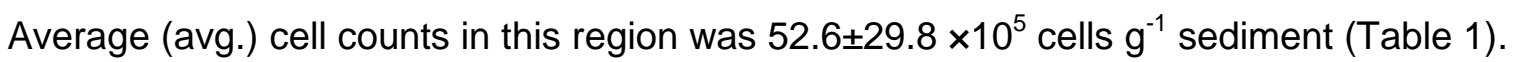
Generally, TC significantly decreased with sediment depth (Suppl. Table 1), although, peaks were recorded at the surface layer of $<2 \mathrm{mbsf}$ and at $\sim 19 \mathrm{mbsf}$ (Fig 1). Maximum 
abundance of $1.03 \times 10^{7}$ cells $\mathrm{g}^{-1}$ sediment was recorded at $0.4-1.4 \mathrm{~m}$. In addition, TC positively correlated with porosity $\left(r^{2}=0.35, p \leq 0.001\right.$, Table 2$)$. TVCa and TVCan

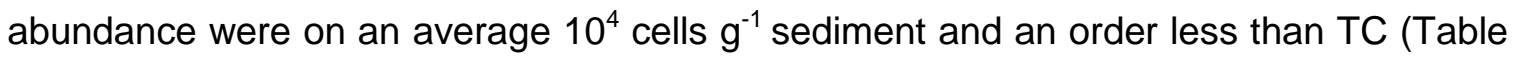
1). TVCa and TVCan did not show any significant interrelationship with each other $\left(r^{2}=0.035\right)$. In addition, TVCa followed a decreasing trend, although three peaks were recorded at different sediment depths (Fig 1). TVCan showed an increasing trend with sediment depth (Suppl. Table 1). However, TVCan significantly correlated with $\mathrm{Fe}$ (II) $\left(r^{2}=0.45, p \leq 0.001\right)$.

\subsection{Distribution of methane, sulfate, and iron and its association with various environmental parameters}

Methane concentrations ranged between non detectable levels (ndl) to $3706 \mathrm{ppm}$ and significantly increased $(p \leq 0.001)$ with depth (Table 1 ). A peak was recorded at $\sim 7-8$ mbsf. $\mathrm{SO}_{4}{ }^{2-}$ concentrations varied between $17.78-28.38 \mathrm{mM}$ and showed an increasing trend up to a depth of $5 \mathrm{mbsf}$. The concentration then decreased steeply at a depth of 78 mbsf and peaked again at $\sim 25$ mbsf only to reduce again further. Fe(II) ranged between ndl to 0.96 (avg. 0.32 \pm 0.26$) \mathrm{mmol} \mathrm{g}^{-1}$ sediment and varied with depth in an irregular manner. The addition of hydroxylamine $(\mathrm{Hy})$ and $\mathrm{HCl}$ as an extractant to the sediment resulted in an increase in reactive $\mathrm{Fe}$ (II) that was higher than adsorbed $\mathrm{Fe}$ (II) concentrations. Hy-Fe and $\mathrm{HCl}-\mathrm{Fe}$ extractable $\mathrm{Fe}$ (II) fractions accumulated over a period of $24 \mathrm{~h}$ and was on an average of $0.86 \pm 1.44$ and $1.90 \pm 2.47 \mathrm{mmol} \mathrm{g}^{-1}$ sediment, respectively (Table 1). Thus addition of these extractants resulted in $\mathrm{Fe}(\mathrm{II})$ concentration that was 27 to 57 times higher than adsorbed $\mathrm{Fe}$ (II). Depth wise, the $\mathrm{Fe}(\mathrm{II})$ and $\mathrm{Hy}-\mathrm{Fe}$ did not show a consistent trend in distribution, while, $\mathrm{HCl}-\mathrm{Fe}$ concentrations increased with depth (Fig. 2). Pearson's correlation analysis revealed that methane concentration correlated negatively with porosity $\left(r^{2}=0.23, p \leq 0.004\right)$ and TC $\left(r^{2}=0.24, p \leq 0.004\right)$. Interrelationship between $\mathrm{SO}_{4}{ }^{2-}$ concentration and methane $\left(r^{2}=0.21, p \leq 0.01\right)$ and TVCa $\left(r^{2}=0.18, p \leq 0.05\right)$ were not significant. Concentrations of $\mathrm{HY}-\mathrm{Fe}$ and $\mathrm{HCl}-\mathrm{Fe}$ correlated significantly $\left(r^{2}=0.28\right.$, Table 2). Although, $\mathrm{HCl}-\mathrm{Fe}$ fractions correlated with $\mathrm{Fe}$ (II) $\left(r^{2}=0.16, p \leq 0.05\right), \mathrm{SO}_{4}^{2-}\left(r^{2}=0.18, p \leq 0.05\right)$ and $\mathrm{TC}\left(r^{2}=0.15, p \leq 0.05\right)$, the interrelationships were not significant.

\subsection{Iron reduction and methane oxidation by indigenous microflora}


Over the duration of a 5-day experiment, results showed that the average methane concentration in the sediment slurries was $0.56 \pm 0.76 \mathrm{ppb}$. However, in surficial sediments and at $57 \mathrm{mbsf}$, the concentration of methane increased over $500 \mathrm{ppb}$ (Fig. 3a) with a corresponding decrease in the $\mathrm{Fe}$ (II) concentration. Also a decrease in methane concentrations at $\sim 38 \mathrm{mbsf}$ had a corresponding increase in $\mathrm{Fe}$ (II) concentrations. In the sediment slurries $\mathrm{Fe}$ (II) concentrations ranged from ndl to 1.08 $\mathrm{mmol} \mathrm{g}^{-1}$ sediment with an average of $0.50 \pm 0.27 \mathrm{mmol} \mathrm{g}^{-1}$ sediment (Fig 3b). The $\mathrm{Fe}$ (II) concentrations at the end of 5-day was significantly higher (ANOVA, $F=6.74, p \leq 0.014$ ) than the 0-day. Iron reducing activity was negligible in the control tubes containing sodium azide (data not shown). Sodium azide is a known microbial growth inhibitor. Linear correlation analysis showed a significant negative interrelationship between $\mathrm{Fe}$ (II) concentration and methane production $\left(r^{2}=0.31, p \leq 0.001, n=36\right.$, Fig. $\left.3 c\right)$.

\section{Discussion}

\subsection{General distribution of bacterial abundance down the sediment core}

Arabian Sea is one of the most productive regions of the world with a characteristic monsoon induced upwelling followed by the development of an oxygen minimum zone in the water body (Wyrtki, 1971; Madhupratap et al., 1996; Naidu, 1998). The monsoon induced upwelling brings about high productivity in the Arabian Sea which leads to a continuous accumulation of organic matter. Arabian Sea is unique as it is surrounded on its three sides by areas which contain deserts. The windborne dust containing iron from these areas probably contributes to the excess iron concentration in the water column which ultimately settles at the bottom sediments (Measures and Vink, 1999; Witter et al., 2000). Due to the ability of iron to oxidize and reduce, iron has been known to drive many reactions involving cycles of carbon, nitrogen, phosphorus, sulphur etc. Bacteria are known to play a major role in these different cycles (Madsen, 2011). Comparison of Arabian Sea subseafloor cell abundance to that of other subseafloor sediments was similar. In addition, the decrease in TC with depth is consistent with the general depth distribution pattern of microbial abundance (Parkes, et al., 1994, 2000, D'Hondt et al., 2004, Roussel et al., 2008). The occurrence of high percentage of clay between 80 $100 \%$ in the studied sedimentary core (Collett et al., 2007) might have a possible role in the distribution of the bacterial abundance in the Arabian Sea sediments. Numerous studies have suggested that bacterial communities in the sediment are considerably influenced by various sedimentological properties such as pore size and mineral 

et al. (2002) while studying the deep-sea siltstone collected from the Japan Trench suggested that the distribution of the microbial communities apparently correlated with the porosity and permeability of the geological matrices. In the present study too, the cell numbers significantly correlated $\left(r^{2}=0.35, p \leq 0.001\right)$ with porosity. In turn, porosity was also correlated to depth which could be co-correlated to pressure, organic carbon availability, etc (Ying et al., 2012). However, in the present study these parameters have not been measured.

TVCa is generally used as a representative to estimate metabolically active forms under aerobic conditions (Kogure et al., 1979) and also accounts for the facultative anaerobes. TVCa decreased with depth yet their presence was recorded even at 63 mbsf. Moreover, peaks in abundance were recorded at different depth suggesting the possibility of metabolically different communities at various depths, where the presence of facultative anaerobes cannot be ruled out. Facultative anaerobes have been isolated from a depth of $900 \mathrm{mbsf}$ in sediments of Sea-do located towards the western part of Dokdo Island in the East Sea of Republic of Korea (Chang et al, 2013). In addition, the present study also showed that there was no significant correlation between TVCa and TVCan indicating that the overlap between these two groups was less, possibly suggesting an existence of physiologically different communities. This supports our observation on the presence of facultative anaerobes. TVCan increased with depth reflecting that these anaerobic forms thrived under increasing anaerobic conditions. Previous studies of deep subseafloor sediments have also reported the existence of microbial cells that exhibit anaerobic metabolic activity (Roussel et al., 2008, D'Hondt et al., 2009). Moreover, reducing conditions in this sediment core were recorded by Collett et al (2007). The strong correlation between abundance of TVCan and Fe(II) $\left(r^{2}=0.44\right.$, $p \leq 0.001)$ may be attributed to the involvement of this anaerobic community in the iron oxide reduction.

\subsection{Distribution of methane, sulfate and iron, and its association with environmental parameters}

Methane is a well known greenhouse gas and has mass-based warming potential up to 72 times greater than carbon dioxide (ICCP, 2007). In the Arabian Sea sediments the distribution of methane, sulfate and iron and their interrelationship clearly demonstrated the presence of a significant potential for iron reduction and methane oxidation. 
In the present study, sulfate increased up to $5 \mathrm{mbsf}$ and decreased concomitantly when methane started to build up at $~ 7 \mathrm{mbsf}$, indicating a sulfate-methane transition zone (Iversen and Jørgensen, 1985, Martens and Berner, 1977). Below this zone, sulfate apparently regenerated. Regeneration of sulfate concentrations may be attributed to different reasons. One of the possibilities could be the regeneration of sulfate from seawater contamination aduring drilling. The other possibility could be due to the downward diffusing sulfide reacting with $\mathrm{Fe}(\mathrm{III})$ species, which is present in the form of poorly-reactive iron oxides or iron bound in reactive silicates (Holmkvist et al., 2011). Furthermore, $\mathrm{HCl}$ extractable $\mathrm{Fe}(\mathrm{II})$ is often associated with solid phase $\mathrm{Fe}$ such as acidsoluble minerals like FeS (van der Zee et al., 2002). This may explain the weak interrelationship $\left(r^{2}=0.18, p \leq 0.05\right)$ of $\mathrm{HCl}-\mathrm{Fe}$ with sulfate. The background concentration of sulfate in these sediments was $23.19 \pm 3.70 \mathrm{mM}$. In these sediments, $\mathrm{H}_{2} \mathrm{~S}$ was not detectable at concentrations $<20$ ppmv (Collett et al., 2007). FeS, green mottling and bands with $\mathrm{Fe}$ (II)-rich clays have also been observed in this sediment core (Collett et al., 2007). The hydrogen sulfide produced by sulfate reduction, subsequently reacts with reactive iron to produce iron sulphide as an initial product and consequently pyrite $\left(\mathrm{FeS}_{2}\right)$ (Rickard and Luther, 1997, Schoonen, 2004).

Interrelationship between methane and sulfate was weak $\left(r^{2}=0.21, p \leq 0.001\right)$. The average methane concentration was $\sim 1.3 \mathrm{ppm}$ in the sediments. On the other hand in these sediments, concentration of $\mathrm{CO}_{2}$ was $0.46 \pm 0.17 \mathrm{mM}$ pw while methane concentrations $>20$ ppmv were only considered for recording for gas hydrate detection, on board (Collett et al., 2007). It is a known fact that in sulfate-linked AOM, the end product of methane oxidation is $\mathrm{CO}_{2}$ with the reduction of sulfate to hydrogen sulfide (Joye, 2012). Taken together, it is probable that the hydrogen sulfide formed possibly combines with $\mathrm{Fe}$ to produce $\mathrm{FeS}$ and subsequently $\mathrm{FeS}_{2}$ which may influence the initiation of metal-oxide dependent AOM.

The Fe(III)-bearing minerals increased continuously with sediment depth and is indicated by the increase in the content of reactive iron in the form of hydroxylamine extractable iron and $\mathrm{HCl}$ extractable fractions of $\mathrm{Fe}$. In particular, addition of hydroxylamine and $\mathrm{HCl}$ as extractants resulted in $\mathrm{Fe}$ (II) concentrations that were 27-57 times higher than adsorbed $\mathrm{Fe}$ (II) (avg. $0.32 \pm 0.26 \mathrm{mmol} \mathrm{g}^{-1}$ sediment) indicating the availability of iron for microbial use as an energy source. Fe(II) significantly correlated with TVCan $\left(r^{2}=0.44\right.$, $p \leq 0.001$ ) implying that the anaerobic fraction of metabolically active microbial cells were actively involved in the iron cycling. Although weak, TVCan and $\mathrm{HCl}-\mathrm{Fe}$ related to each 
other $\left(r^{2}=0.11, p \leq 0.05\right) . \mathrm{HCl}$ extraction of iron is usually a proton promoted dissolution and it is possible that the anaerobic viable forms may be using the proton-promoted mechanism for the dissolution of Fe oxides. Proton-promoted dissolution is one of the mechanisms that have been suggested for dissolution of Fe oxides for microorganisms in deep terrestrial subsurface due to their inherent ability to produce acidic conditions by excreting organic acids (Hersman, 1997). It may be noted here that $\mathrm{HCl}-\mathrm{Fe}$ fractions positively correlated with $\mathrm{Hy}-\mathrm{Fe}\left(r^{2}=0.28, \mathrm{p}<0.004\right)$. A possible explanation of this correlation, is that the $\mathrm{HCl}-\mathrm{Fe}$ extractable fraction represent $\mathrm{Fe}(\mathrm{III})$ oxide assemblages spanning amorphous $\mathrm{Fe}(\mathrm{III})$ oxides and is possibly extracted by $\mathrm{HCl}$. Further, the amorphous $\mathrm{Fe}(\mathrm{III})$ (hydr)oxide could also be extracted with hydroxylamine-HCl (Lovley and Phillips, 1987).

\subsection{Iron reduction and methane oxidation by indigenous microflora in microcosms containing Kerala-Konkan basin sediments}

Production of $\mathrm{Fe}(\mathrm{II})$ in sediment slurries with native microflora increased with time. There was significant difference (ANOVA, $F=6.74, p \leq 0.014$ ) in the concentrations of $\mathrm{Fe}(\mathrm{II})$ between the 0 -day and $5^{\text {th }}$ day. In the control tubes i.e. in the presence of sodium azide, the process of iron reduction was inhibited. Sodium azide has previously been shown to inhibit iron reduction (Fernandes et al. 2011). The build-up of $\mathrm{Fe}(\mathrm{II})$ in the experimental tubes was accompanied by the disappearance of methane (Fig. 3c). A strong negative linear correlation $\left(r^{2}=0.31, p \leq 0.001\right)$ of methane concentration with the adsorbed $\mathrm{Fe}(\mathrm{II})$ suggests that increasing rates of microbial iron reduction caused a suppression in methane production. Abundance of $\mathrm{Fe}(\mathrm{III})$-bearing minerals have been suggested to have a potential for a coupling of $\mathrm{AOM}$ to $\mathrm{Fe}(\mathrm{III})$ reduction in sediments (Wankel et al., 2012). Moreover, iron oxides, manganese oxides, and/or nitrate, have been known to serve as alternate electron acceptors for AOM (Raghoebarsing et al., 2006, Beal et al., 2009, Sivan et al., 2011). Studies have demonstrated that, poorly crystalline Fe(III) oxides present in sediments were capable of inhibiting methane production (Lovley and Phillips, 1987; Roden and Wetzel, 1996; Frenzel et al., 1999; Yao and Conrad, 1999; Chidthaisong and Conrad, 2000). Moreover, when Fe(III) is present in the sediment, $\mathrm{Fe}(\mathrm{III})$-reducing organisms are known to divert electron flow away from sulfate reduction and methane production even though there were populations of potentially active sulfate reducers and methanogens in the sediments (Lovley et al., 1987). It may be recalled 
here that percentage of clay in these sediments is around $80-100 \%$ and the average adsorbed $\mathrm{Fe}$ (II) concentration and reactive $\mathrm{Fe}$ like hydroxylamine and $\mathrm{HCl}$ extractable Fe was $0.32 \pm 0.26,0.86 \pm 1.44$ and $1.90 \pm 2.47 \mathrm{mmol} \mathrm{g}^{-1}$ sediment, respectively. The high percentage of clay as well as the concentration of reactive species of $\mathrm{Fe}$ in these sediments implies the potential availability of $\mathrm{Fe}$ (III) for iron reduction. Studies on marine sediments have shown that a fraction of iron is released from structurally coordinated $\mathrm{Fe}^{3+}$ of clay minerals by microbial extraction (Vorhies and Gaines, 2009).

In conclusion, the Arabian Sea sediments have a bacterial abundance between $10^{5-7}$ cells $\mathrm{g}^{-1}$ sediment. Statistical analysis indicated that ferrous interrelated with anaerobic fraction of viable bacteria suggesting that this fraction of metabolically active bacteria was also involved in cycling of iron. In these sediments, besides other factors, iron reduction also seemed to influence methane oxidation rates. Thus, the presence of both methane oxidation and iron reduction activities in the Arabian Sea sediment indicates the co-occurrence of their indigenous physiological microbial groups with the potential to carry out these activities.

\section{Acknowledgement}

The authors are grateful to Director, Council of Scientific and Industrial Research National Institute of Oceanography for providing the facilities to conduct the research work. Thanks are extended to the project leader Shri T. Ramprasad of "Integrated studies to understand the behavior of the geobiological environs in deciphering gas hydrate occurrence along the Indian continental margins" for the encouragement and constant support. The author(s) wish to thank those that contributed to the success of the National Gas Hydrate Program Expedition 01 (NGHP01). NGHP01 was planned and managed through collaboration between the Directorate General of Hydrocarbons (DGH) under the Ministry of Petroleum and Natural Gas (India), the U.S. Geological Survey (USGS), and the Consortium for Scientific Methane Hydrate Investigations (CSMHI) led by Overseas Drilling Limited (ODL) and FUGRO McClelland Marine Geosciences (FUGRO). The platform for the drilling operation was the research drill ship JOIDES Resolution, operated by ODL. Much of the drilling/coring equipment used was provided by the Integrated Ocean Drilling Program (IODP) through a loan agreement with the US National Science Foundation. Wireline pressure coring systems and supporting laboratories were provided by IODP/Texas A\&M University (TAMU), FUGRO, 
USGS, U.S. Department of Energy (USDOE) and HYACINTH/GeoTek. Downhole logging operational and technical support was provided by Lamont-Doherty Earth Observatory (LDEO) of Columbia University. The financial support for the NGHP01, from the Oil Industry Development Board, Oil and Natural Gas Corporation Ltd., GAIL (India) Ltd. and Oil India Ltd. is gratefully acknowledged. We also acknowledge the support extended by all the participating organizations of the NGHP: MoP \& NG, DGH, ONGC, GAIL, OIL, NIO, NIOT, and RIL. The authors record their thankfulness to Dr. Tim Collett, crew members of DV JOIDES resolution, and NGHP-01-01 shipboard science party

members for onboard facilities and samples. Support from Council of Scientific and Industrial Research, India for the research fellowship of CEGF is gratefully acknowledged. This is NIO contribution no.

\section{References}

Atlas, R.M. 2004. Handbook of Microbiological media. CRC press, LLC.

Beal, E.J., House, C.H., Orphan, V.J. 2009. Manganese- and iron dependent marine methane oxidation. Science 325, 184-187.

Biddle, J.F., Lipp, J.S., Lever, M.A., Lloyd, K.G., Sørensen, K.B., Anderson, R., Fredricks, H.F., Elvert, M., Kelly, T.J., Schrag, D.P., Sogin, M.L., Teske, A., House, C.H., Hinrichs, K-U. 2006. Heterotrophic Archaea dominate sedimentary subsurface ecosystems off Peru. PNAS 103, 3846-3851.

Boetius, A., Ravenschlag, K., Schubert, C.J., Rickert, D., Widdel, F., Gieseke, A., Amann, R., Jorgensen, B.B., Witte, U., Pfannkuche, O. 2000. A marine microbial consortium apparently mediating anaerobic oxidation of methane. Nature 407, 623-626.

Bond, D.B., Lovley, D.R. 2002. Reduction of Fe(III) oxide by methanogens in the presence and absence of extracellular quinines. Environ. Microbiol. 4, 115-124.

Bruchert, V., Currie, B., Peard, K. R., Lass, U., Endler, R., Dubecke, A., Julies, E., Leipe, T., Zitzmann, S. 2006. Biogeochemical and physical control on shelf anoxia and water column hydrogen sulphide in the Benguela upwelling system off Namibia, In: Neretin, L. N. (Eds.), Past and Present Water Column Anoxia, NATO Science Series, IV. Earth and Environmental Sciences, Springer, Dordrecht, 64, 161-193. Carson, J.K., Campbell, L., Rooney, D., Clipson, N., Gleeson, D.B. 2009. Minerals in soil select distinct bacterial communities in their microhabitats. FEMS Microbiol. Ecol. 67, 381-388. 
Chang, D-H., Lee, J-B., Lee, G-H., Rhee, M-S., Lee, H., Bae, K.S., Park, D-S., Kim, B-C. 2013. Sunxiuqinia dokdonensis sp. nov., isolated from deep sub-seafloor sediment. J. Microbiol. 51, 741-746.

Chidthaisong, A., and Conrad, R. 2000. Turnover of glucose and acetate coupled to reduction of nitrate, ferric iron, and to methanogenesis in anoxic field soil. FEMS Microbiol. Ecol. 31, 73-86.

Clesceri, L.S., Greenberg, A.E., and Eaton, A.D. 1998. Standard methods for the Examination of water and waste water $\left(20^{\text {th }}\right.$ edition). American Public Health Association, Washington.

Coates, J.D., Anderson, R.T., Woodwar, J.C., Phillips, E.J., and Lovley, D.R. 1996. Anaerobic hydrocarbon degradation in petroleum-contaminated harbor sediments under sulfate-reducing and artificially imposed iron-reducing conditions. Environ. Sci. Technol. 30, 2784-2789.

Collett, T.S., Riedel, M., Cochran, J., Boswell, R., Presley, J., Kumar, P., Sathe, A.V., Sethi, A.K., Lall, M., Sibal, V.K. and The NGHP Exp. 01 Scientists. 2007. NGHP expedition 01 (2006), Initial reports, Directorate General of Hydrocarbons, NOIDA and Ministry of Petroleum \& Natural Gas, India, 4 volumes.

Deutzmann, J.S., Schink, B. 2011. Anaerobic oxidation of methane in sediments of Lake Constance, an oligotrophic freshwater lake. Appl. Environ. Microbiol. 77, 44294436.

D'Hondt, S., Jorgensen, B.B., Miller, D.J., Batzke, A., Blake, R., Cragg, B.A., Cypionka, H., Dickens, G.R., Ferdelman, T., Hinrichs, K.U., Holm, N.G., Mitterer, R., Spivack, A., Wang, G., Bekins, B., Engelen, B., Ford, K., Gettemy, G., Rutherford, S.D., Sass, H., Skilbeck, C.G., Aiello, I.W., Guèrin, G., House, C.H., Inagaki, F., Meister, P., Naehr, T., Niitsuma, S., Parkes, R.J., Schippers, A., Smith, D.C., Teske, A., Wiegel, J., Padilla, C.N., Acosta, J.L. 2004. Distributions of microbial activities in deep subseafloor sediments. Science 306, 2216-2221.

D'Hondt, S., Spivack, A.J., Pockalny, R., Ferdelman, T.G., Fischer, J.P., Kallmeyer, J., Abrams, L.J., Smith, D.C., Graham, D., Hasiuk, F., Schrum, H., Stancin, A.M. 2009. Subseafloor sedimentary life in the South Pacific gyre. PNAS 106, 1165111656.

Deming, J.W., Colwell, R.R. 1982. Barophilic bacteria associated wih digestive tracts of abyssal holothurians. Appl. Environ. Microbiol. 44, 1222-1230. 
Fernandes, C.E.G., Velip, D., Mourya, B.S., Shaikh, S., Das, A. and P.A. Loka Bharathi. 2011. Iron released from ilmenite mineral sustains a phytoplankton community in microcosms. Bot. Mar. 54, 419-430.

Frenzel, P., Bosse, U., Janssen, P.H. 1999. Rice roots and methanogenesis in a paddy soil, ferric iron as an alternative electron acceptor in the rooted soil. Soil Biol. Biochem. 31, 421-430.

Gonsalves, M.B., Fernandes, C.E.G., Fernandes, S.O., LokaBharathi. P.A. 2011. Effects of composition of labile organic matter on biogenic production of methane in the coastal sediments of the Arabian Sea. Environ. Monit. Assess. 182, 385-395.

Hersman, L.E. 1997. The microbiology of the terrestrial deep subsurface. Amy, P.S., Haldemann, D.L. (eds.), CRC Press, LLC. pp, 312.

Hobbie, J.E., Daley, R.J., Jasper, S. 1977. Use of Nuclepore filters for counting bacteria by fluorescence microscopy. Appl. Environ. Microbiol. 33, 1225-1228.

Holmkvist, L., Ferdelman, T.G., Jørgensen, B.B. 2011. A cryptic sulfur cycle driven by iron in the methane zone of marine sediment (Aarhus Bay, Denmark). Geochim. Cosmochim. Acta 75, 3581-3599.

Inagaki, F., Nunoura, T., Nakagawa, S., Teske, A., Lever, M., Lauer, A., Suzuki, M., Takai, K., Delwiche, M., Colwell, F.S., Nealson, K.H., Horikoshi, K., D’Hondt, S., Jorgensen, B.B. 2006. Biogeographical distribution and diversity of microbes in methane hydrate-bearing deep marine sediments on the Pacific Ocean Margin. PNAS 103, 2815-2820.

Inagaki, F., Sakihama, Y., Takai, K., Komatsu, T., Inoue, A., Horikoshi. K. 2002. Profile of microbial community structure and presence of endolithic microorganisms inside a deep-sea rock. Geomicrobiol. J. 19, 535-552.

Inagaki, F., Suzuki, M., Takai, K., Oida, H., Sakamoto, T., Aoki, K., Nealson, K.H., Horikoshi, K. 2003. Microbial communities associated with geological horizons in coastal subseafloor sediments from the Sea of Okhotsk. Appl. Environ. Microbiol. 69, 7224-7235.

IPCC, Climate Change 2007, The Physical Science Basis. Contribution of Working Group I to the Fourth Assessment Report of the Intergovernmental Panel on Climate Change, Cambridge University Press, Cambridge, United Kingdom, 2007. 
Iversen, N., Jorgensen, B.B. 1985. Anaerobic methane oxidation rates at the sulfatemethane transition in marine sediments from Kattegat and Skagerrak (Denmark). Limnol. Oceanogr. 30, 944-955.

Jorgensen, B.B., Boetius, A. 2007. Feast and famine - microbial life in the deep-sea bed. Nature Rev. Microbiol. 5, 770-781.

Joux, F., LeBaron, P. 1997. Ecological implications of an improved direct viable count method for aquatic bacteria. Appl. Environ. Microbiol. 63, 3643-3647.

Joye, S.B. 2012. A piece of the methane puzzle. Nature 491, 538-539.

Kallmeyer, J., Smith, D.C., Spivack, A.J., D'Hondt, S. 2008. New cell extraction procedure applied to deep subsurface sediments. Limnol. Oceanogr. Methods 6 , 236-245.

Kallmeyer, J., Pockalny, R., Adhikari, R.R., Smith, D.C., D'Hondt, S. 2012. Global distribution of microbial abundance and biomass in subseafloor sediment. PNAS 109, 16213-16216.

Kostka, J.E., Haefele, E., Viehweger, R., Stucki, J.W. 1999. Respiration and dissolution of Iron(III)-containing Clay minerals by bacteria. Environ. Sci. Technol. 33, 31273133

Kerkar, S., Loka Bharathi, P.A. 2011. G model re-visited: Seasonal changes in the kinetics of sulfate reducing activity in the salterns of Ribander, Goa, India. Geomicrobiol. J. 28, 187-197.

Knittel, K., Boetius, A. 2009. Anaerobic oxidation of methane, progress with an unknown process. Annu. Rev. Microbiol. 63, 311-334.

Kogure, K., Simidu, U., Taga, N. 1979. A tentative direct microscopic count for counting living marine bacteria. Can. J. Microbiol. 25, 415-420.

Legendre, P., Legendre, L., 1998. Complex ecological data sets. In: Legendre, P. and Legendre, L. (Eds.), Developments in environmental modelling, 20. Numerical ecology. Il edition. Elsevier, Amsterdam. pp. 1-853.

Loka Bharathi, P.A., Nair, S., DeSouza, M.J.B.D., Chandramohan, D. 1999. Truce with oxygen-Anaerobiosis outcompete aerobiosis in the Antarctic lacustrine bacteria. Curr. Sc. 76, 1585-1587.

Lovley, D.R., Phillips, E.J.P. 1986. Availability of ferric iron for microbial reduction in bottom sediments of freshwater tidal Potomac river. Appl. Environ. Microbiol. 52, 751-757. 
Lovley, D.R., Phillips, E.J.P. 1987. Rapid assay for microbially reducible ferric iron in aquatic sediments. Appl. Environ. Microbiol. 53, 1536-1540.

Martens, C.S., Berner, R.A. 1977. Interstitial water chemistry of anoxic Long Island Sound sediment. 1. Dissolved gases. Limnol. Oceanogr. 22, 10-25.

Madhupratap, M., Prasanna Kumar, S., Bhattathiri, P.M.A., Dileep Kumar, M., Raghukumar, S., Nair, K.K.C., Ramaiah, N. 1996. Mechanism of the biological response to winter cooling in the northeastern Arabian Sea, Nature. 384, 549552.

Madsen EL ,2011 Bacteria are known to play a major role in these different cycles .

Measures, C.I., Vink, S. 1999. Seasonal variations in the distribution of Fe and $\mathrm{Al}$ in the surface waters of the Arabian Sea. Deep-Sea Res., Part 2, Top. Stud. Oceanogr. 46, 1597-1622.

Naidu, P.D., 1998. Driving forces of Indian summer monsoon on Milankovitch and subMilancovitch time scales: A review. J. Geol. Soc. India, 52, 257-272.

Nakibuuka et al, 2012. Qualitative Determination of Methane Gas at Selected Sites in Kampala City, Uganda. The Open Environmental Engineering Journal 5, 50-55.

Naroi, K., Thamdrup, B. 2014. Nitrate-dependent anaerobic methane oxidation in a freshwater sediment. Geochim. Cosmochim. Acta, 132, 141-150.

Nielsen, J.L., Juretschko, S., Wagner, M. and Nielsen, P.H. 2002. Abundance and phylogenetic affiliation of iron reducers in activated sludge as assessed by fluorescence in situ hybridization and microautoradiography. Appl. Environ. Microbiol. 68, 4629-4636.

Orcutt, B.N., Sylvan, J.B., Knab, N.J., Edwards, K.J. 2011. Microbial ecology of the dark ocean above, at and below the seafloor. Microbiol. Mol. Biol. Rev. 72, 361-422.

Parkes, R.J., Cragg, B.A., Bale,S.J., Getliff, J.M. Goodman, K.P., Rochelle, A., Fry, J.C., Weightman, A.J., Harvey, S.M. 1994. Deep bacterial biosphere in Pacific Ocean sediments. Nature 371, 410-413.

Parkes, R.J., Cragg, B.A., Wellsbury, P. 2000. Recent studies on bacterial populations and processes in subseafloor sediments: A review. Hydrogeol. J. 8, 11-28.

Parkes, R.J., Webster, G., Cragg, B.A., Weightman, A.J., Newberry, J., Ferdelman, T.G., Kallmeyer, J., Jorgensen, B.B., Aiello, I.W., Fry, J.C. 2005. Deep sub-seafloor prokaryotes stimulated at interfaces over geologic time. Nature 436, 390-394. 
Pattan, J.N., Parthiban, G., Gupta, S.M., Mir, I.A. 2012. Fe speciation and Fe/Al ratio in the sediments of southeastern Arabian Sea as an indicator of climate change. Quatern. Int. 250, 19-26.

Raghoebarsing, A.A., Pol, A., van de Pas-Schoonen, K.T., Smolders, A.J.P., Ettwig, K.F., Rijpstra, W.I.C., Schouten, S., Damste, J.S.S., Op den Camp, H.J.M., Jetten, M.S.M., Strous, M. 2006. A microbial consortium couples anaerobic methane oxidation to denitrification. Nature 440, 918-921.

Reeburgh, W.S., 1996. "Soft spots" in the global methane budget. In, Microbial Growth on C-1 Compounds, Lidstrom, M.E., Tabita, F.R., (eds.) Kluwer Academic Publishers, Dorcrecht, pp 335-342.

Reeburgh, W.S., 2007. Oceanic methane biogeochemistry. Chemical Reviews 107, 486-513.

Reeburgh, W.S., Whalen, S.C., Alperin, M.J. 1993. The role of methylotrophy in the global methane budget. In, Microbial growth on $\mathrm{C}_{1}$ compounds. Proceedings of the 7th International Symposium. Murrell, J.C., Kelly, D.P. (Eds.) American Society for Microbiology, Washington, D.C. pp 1-14.

Reed, D.W., Fujita, Y., Delwiche, M.E., Blackwelder, D.B., Sheridan, P.P., Uchida, T. Colwell, F.S. 2002. Microbial communities from methane hydrate-bearing deep marine sediments in a forearc basin. Appl. Environ. Microbiol. 68, 3759-3770.

Rickard, D.T., Luther, G.W., III. 1997. Kinetics of pyrite formation by the $\mathrm{H}_{2} \mathrm{~S}$ oxidation of iron (II) monosulphide in aqueous solutions between 25 and $125 \square^{\circ} \mathrm{C}$ : The mechanism. Geochim. Cosmochim. Acta, 61, 135-147.

Riedinger, N., Formolo, M.J., Lyons, T.W., Henkel, S., Beck, A., Kasten, S. 2014. An inorganic geochemical argument for coupled anaerobic oxidation of methane and iron reduction in marine sediments. Geobiology 12, 172-181.

Roden, E.E., Wetzel, R.G. 1996. Organic carbon oxidation and suppression of methane production by microbial $\mathrm{Fe}$ (III) oxide reduction in vegetated and unvegetated freshwater wetland sediments. Limnol. Oceanogr. 41, 1733-1748.

Roszak, D. B., Colwell, R. R. 1987. Metabolic activity of bacterial cells enumerated by direct viable count. Appl. Environ. Micro. 53, 2889-2983.

Roussel, E.G., Bonavita, M-A.C., Querellou, J., Cragg, B.A., Webster, G., Prieur, D., Parkes, R.J. 2008. Extending the sub-seafloor biosphere. Science 320, 1046. 
Segarra, K.E.A., Comerford, C., Slaughter, J., Joye, S.B. 2013. Impact of electron acceptor availability on the anaerobic oxidation of methane in coastal freshwater and brackish wetland sediments. Geochimic. Cosmochim. Acta 115, 15-30.

Schoonen, M.A.A. 2004, Mechanisms of sedimentary pyrite formation. In: Amend, J.P., Edwards, K.J., Lyons, T.W. (eds.). Sulfur biogeochemistry_Past and Present: Boulder, Colorado, Geological Society of America Special Paper 379, pp. 117134.

Schnetger, B., Brumsack, H-J., Schale, H., Hinrichs, J., Dittert, L. 2000. Geochemical characteristics of deep-sea sediments from the Arabian Sea, a high resolution study. Deep-Sea Res. II 47, 2735-2768.

Sivan, O., Adler, M., Pearson, A., Gelman, F., Bar-Or, I., John, S.G., Eckert, W. 2011. Geochemical evidence for iron-mediated anaerobic oxidation of methane. Limnol. Oceanogr. 56, 1536-1544.

Smith, D.C., Spivack, A.J., Fisk, M.R., Haveman, S.A., Staudigel, H. and ODP Leg 185 Scientific Party, 2000. Methods for quantifying potential microbial contamination during deep ocean coring. ODP Tech. Note, 28 [Onlin]. Available from World wide web:

http://www-odp.tamu.edu/publications/tnotes/tn28/INDEX.HTM.

Stookey, L.L., 1970. Ferrozine, a new spectrophotometric reagent for iron. Anal. Chem. 42, 779-781.

Strong, D.T., de Wever, H., Merckx, R., Recous, S. 2004. Spatial location of carbon decomposition in the soil pore system. Eur. J. Soil Sci. 55, 739-750.

Teske, A. 2013. Marine deep sediment microbial communities. In, The Prokaryotes, Prokaryotic communities and ecophysiology. Rosenberg, E., DeLong, E.R., Lory, S., Stackebrandt, E., Thompson, F. (eds.) Springer Berlin Heidelberg. pp 123138.

Treude, T., Boetius, A., Knittel, K., Wallmann, K. and Jorgensen, B.B. 2003. Anaerobic oxidation of methane above gas hydrates at Hydrate Ridge, NE Pacific Ocean. Mar. Ecol. Prog. Ser. 264, 1-14.

Valentine, D.L., Reeburgh, W.S. 2000. New perspectives on anaerobic methane oxidation. Environ. Microbiol. 2, 477-484.

van der Zee, C., van Raaphorst, W., Helder, W. 2002. Fe redox cycling in Iberian continental margin sediments (NE Atlantic). J. Mar. Res. 60, 855-866. 
Vorhies, J.S., Gaines, R. 2009. Microbial dissolution of clay minerals as a source of iron and silica in marine sediments. Nat. Geosci. 2, 221-225.

Wankel, S.D., Adams, M.M., Johnston, D.T., Hansel, C.M., Joye, S.B., Girguis, P.R., 2012. Anaerobic methane oxidation in metalliferous hydrothermal sediments, influence on carbon flux and decoupling from sulfate reduction. Environ. Microbiol. 14, 2726-2740.

Witter, A.E., Lewis, B.L., Luther, G.W., 2000. Iron speciation in the Arabian Sea. DeepSea Res., Part 2, Top. Stud. Oceanogr. 47, 1517-1539.

Whitman, W.B., Coleman, D.C., Wiebe, W.J., 1998. Prokaryotes: The unseen majority. Proc. Natl. Acad. Sci. USA 95:6578-6583.

Wyrtki, K. 1971. Oceanographic Atlas of the International Indian Ocean Expedition, National Science Foundation, Washington DC, pp. 531

Yao, H., and Conrad, R. 1999. Thermodynamics of methane production in different rice paddy soils from China, the Philippines, and Italy. Soil Biol. Biochem. 31, 463473.

Ying C.Y., Tang Y.K., Jun W., Jun Q., Long Z. 2012. Parameterizing soil organic carbon's impacts on soil porosity and thermal parameters for eastern Tibet grasslands. Sci. China Earth Sci. 55, 1001-1011.

\section{Figure captions}

Fig. 1: Distribution pattern of bacterial parameters down the sediment core up to $63 \mathrm{mbsf}$ Fig. 2: Distribution pattern of different fraction of iron concentration down the sediment core up to $63 \mathrm{mbsf}$

Fig. 3: Methane concentration at 0-day and 5-day (a), Ferrozine-extractable $\mathrm{Fe}$ (II) concentration at 5-day (b) and the linear correlation (c) between the two parameters in a microcosm experiment after 5-day incubation under anaerobic conditions. 
Figure 1
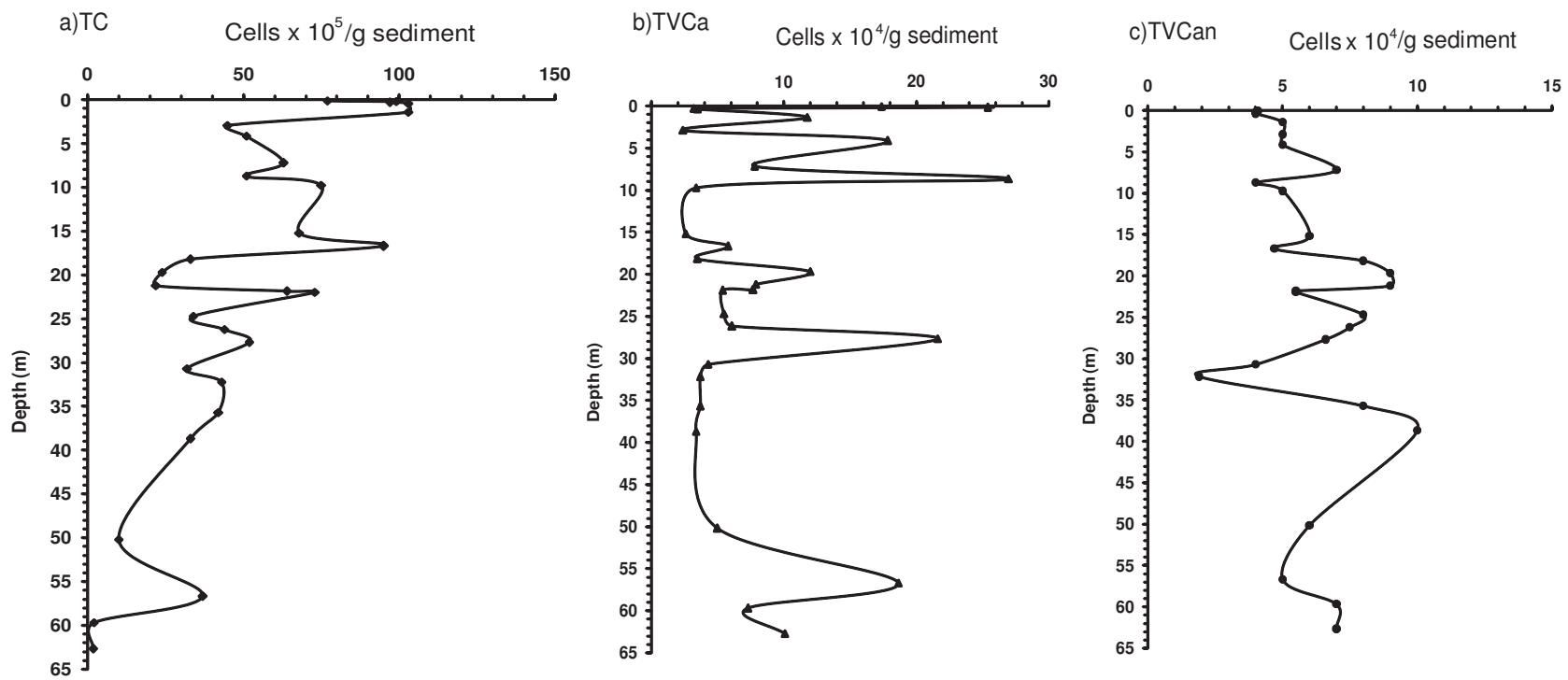


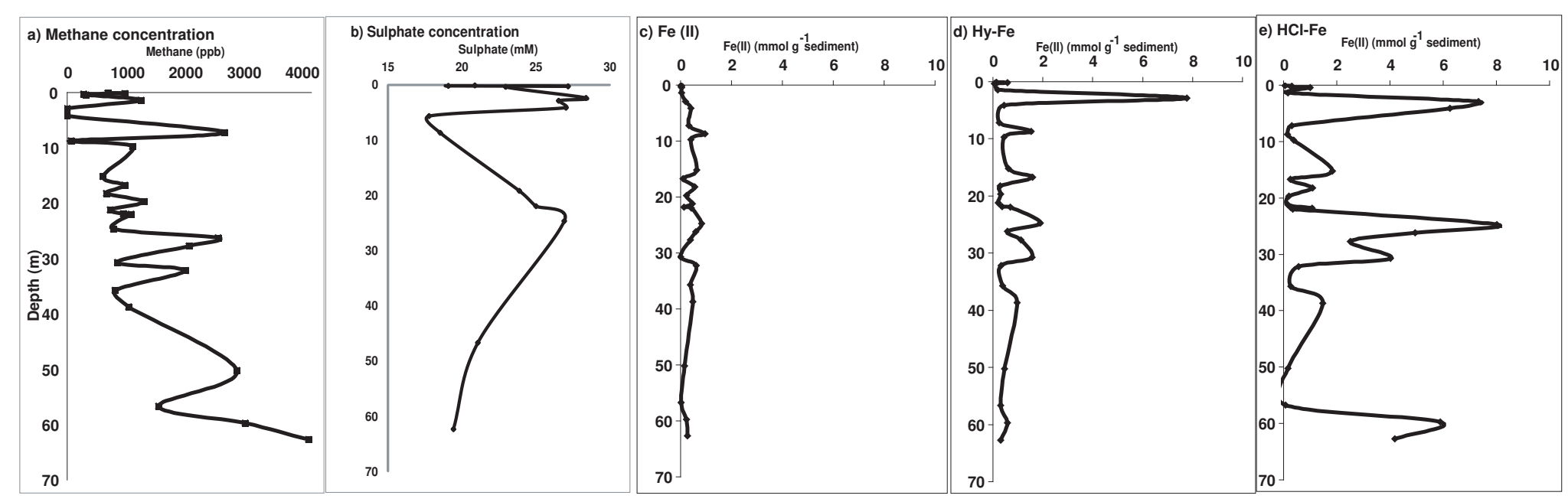

\section{Figure 2}


Figure 3
a) Methane concentration
b) $\mathrm{Fe}$ (II) concentration
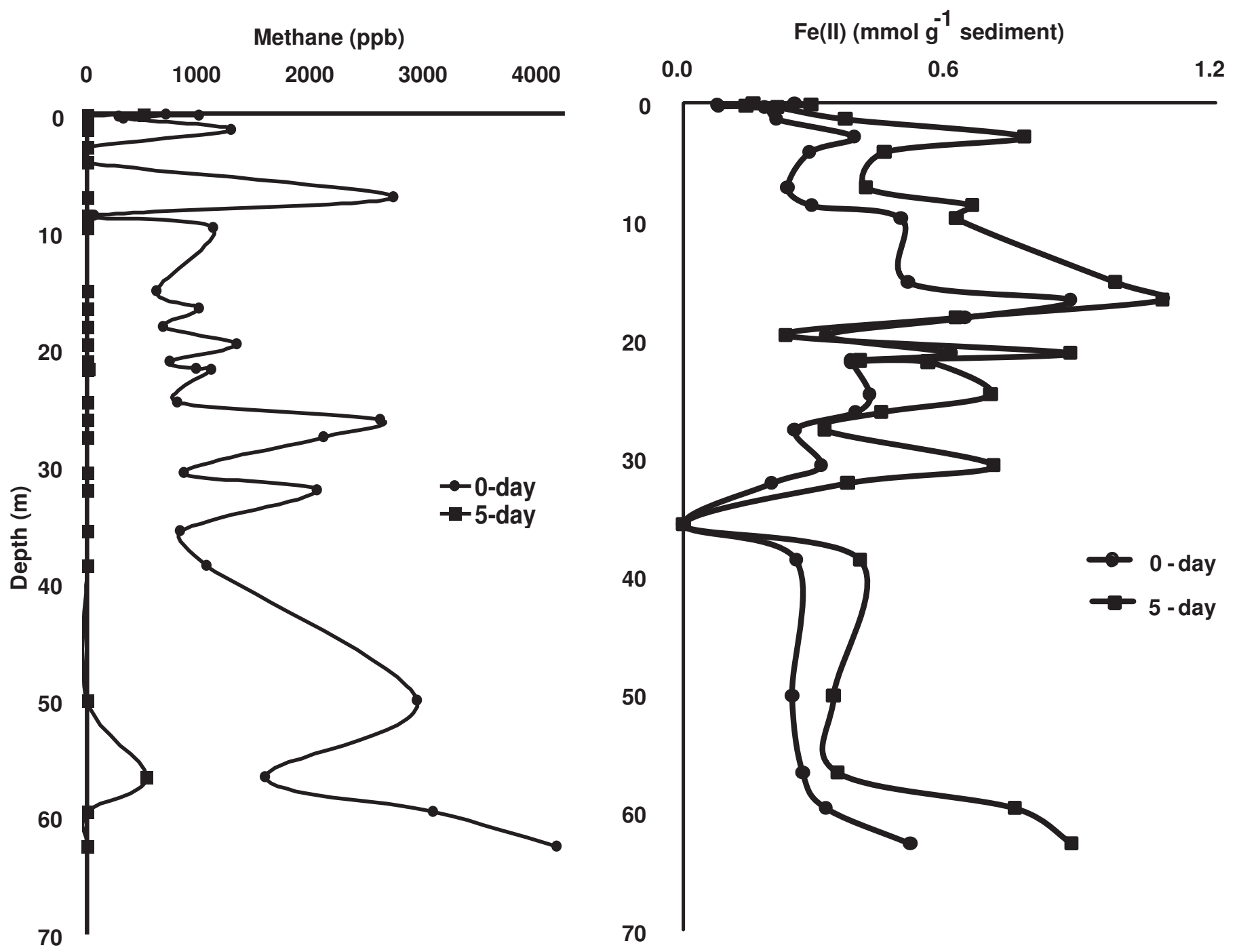

c) Linear correlation between methane and $\mathrm{Fe}$ (II)

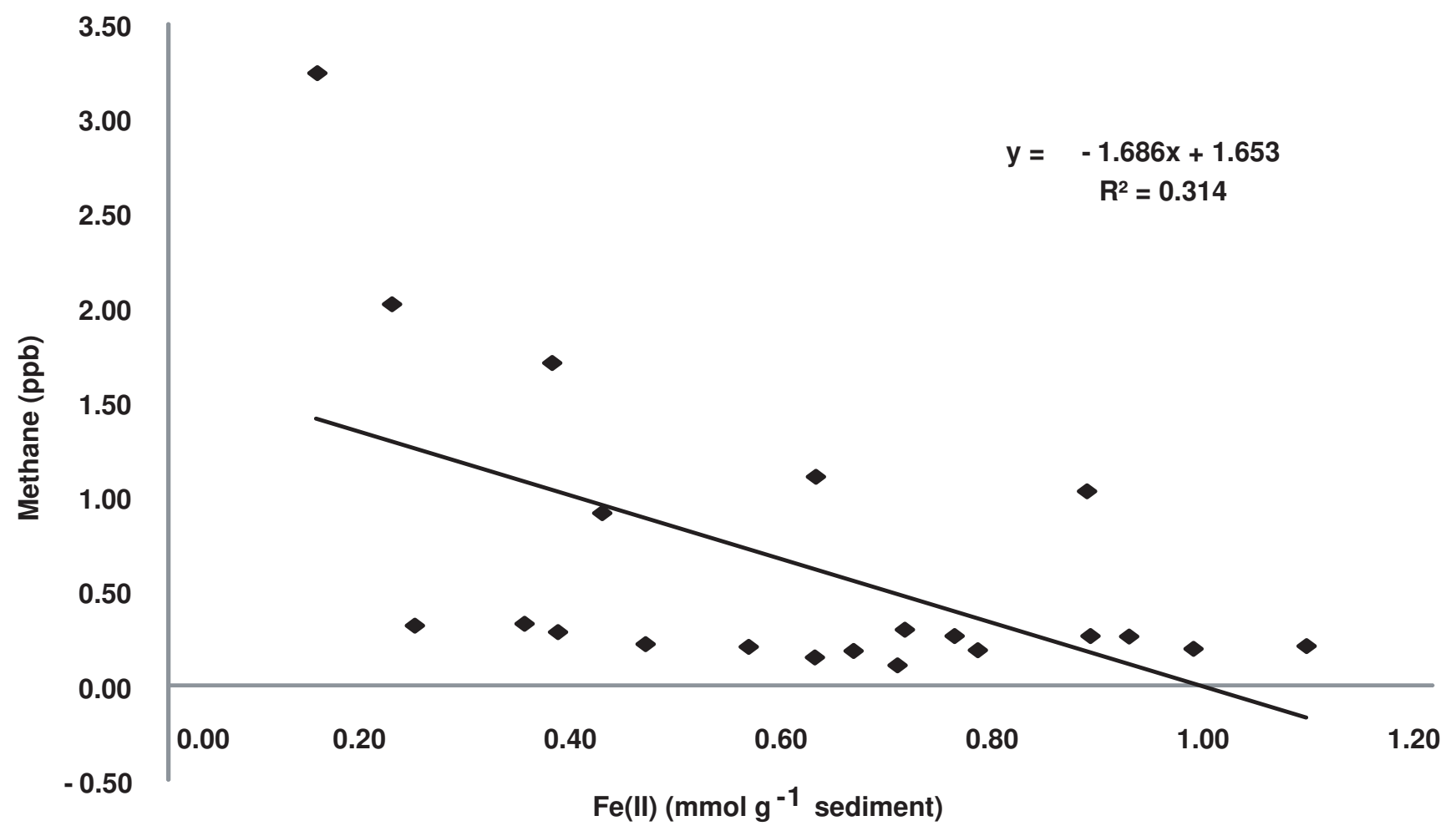


Table 1: Range and average values of various chemical and bacterial parameters obtained from the Konkan-Kerala basin sediment core analyzed up to $63 \mathrm{mbsf}$.

\begin{tabular}{|c|c|c|}
\hline Parameters & Range & avg $\pm s d$ \\
\hline Sulphate (mM) & $17.78-28.38$ & $23.19 \pm 3.70$ \\
\hline Methane (ppb) & ndl - 4149 & $1280 \pm 1022$ \\
\hline $\mathrm{Fe}(\mathrm{II})\left(\mathrm{mmol} \mathrm{g}^{-1}\right)$ & $\mathrm{ndl}-0.96$ & $0.32 \pm 0.26$ \\
\hline $\mathrm{HY}-\mathrm{Fe}\left(\mathrm{mmol} \mathrm{g} \mathrm{g}^{-1}\right)$ & $0.05-7.76$ & $0.86 \pm 1.44$ \\
\hline $\mathrm{HCl}-\mathrm{Fe}\left(\mathrm{mmol} \mathrm{g}^{-1}\right)$ & $0.34-17.62$ & $1.90 \pm 2.47$ \\
\hline${ }^{*} \mathrm{CO}_{2}(\mathrm{mM} \mathrm{pw})$ & $0.2-0.7$ & $0.46 \pm 0.17$ \\
\hline${ }^{*} \mathrm{GD}\left(\mathrm{g}^{-1} \mathrm{~cm}^{3}\right)$ & $2.62-2.80$ & $2.73 \pm 0.03$ \\
\hline *porosity (\%) & $56.03-71.48$ & $65.20 \pm 3.17$ \\
\hline TC $\left(\times 10^{5}\right.$ cells $\left.g^{-1}\right)$ & $1-103$ & $52.6 \pm 29.8$ \\
\hline $\operatorname{TVCa}\left(\times 10^{4}\right.$ cells $\left.\mathrm{g}^{-1}\right)$ & $2.4-27$ & $9.07 \pm 7.20$ \\
\hline TVCan $\left(\times 10^{4}\right.$ cells g $\left.{ }^{-1}\right)$ & $1-10$ & $5.89 \pm 1.99$ \\
\hline
\end{tabular}

avg - average, ndl - non detectable limit, pw - porewater, Fe(II) - ferrous iron, $\mathrm{HY}$ - $\mathrm{Fe}$ - hydroxylamine extractable $\mathrm{Fe}$, $\mathrm{HCl}-\mathrm{Fe}$ - $\mathrm{HCl}$ extractable Fe, GD - grain density, TC - total bacterial counts, TVCa - Viable counts under aerobic conditions, TVCan - Viable counts under anaerobic conditions. *Data obtained from Collett et al. 2007 
Table 2: Pearson's correlation analysis using 10 parameters $(n=36)$. Values denote correlation coefficient, $r^{2}$ values.

$\begin{array}{lccccccc}\text { Parameters } & \text { Depth } & \mathrm{Fe}(\mathrm{II}) & \mathrm{HY}-\mathrm{Fe} & \mathrm{CH}_{4} & { }^{*} \mathrm{GD} & { }^{*} \text { Porosity } & \mathrm{TC} \\ \mathrm{HCl}-\mathrm{Fe} & \mathrm{ns} & \mathrm{ns} & \mathbf{0 . 2 8 1 ^ { * }} & \mathrm{ns} & \mathrm{ns} & \mathrm{ns} & \mathrm{ns} \\ \mathrm{CH}_{4} & \mathbf{0 . 4 8 2}^{*} & \mathrm{~ns} & \mathrm{~ns} & \mathrm{~ns} & \mathrm{~ns} & \mathrm{~ns} & \mathrm{~ns} \\ { }^{+} \mathrm{GD} & \mathbf{0 . 2 2 2}^{*} & \mathrm{~ns} & \mathrm{~ns} & \mathrm{~ns} & \mathrm{~ns} & \mathrm{~ns} & \mathrm{~ns} \\ { }^{+} \text {Porosity } & \mathbf{0 . 6 0 0 ^ { * }} & \mathrm{ns} & \mathrm{ns} & \mathbf{0 . 2 3 1 ^ { * }} & \mathbf{0 . 3 0 9 ^ { * }} & \mathrm{ns} & \mathrm{ns} \\ { }^{\text {TC }} & \mathbf{0 . 6 0 0 ^ { * }} & \mathrm{ns} & \mathrm{ns} & \mathbf{0 . 2 4 1 ^ { * }} & \mathrm{ns} & \mathbf{0 . 3 4 9 ^ { * }} & \mathrm{ns} \\ \text { TVCan } & \mathrm{ns} & \mathbf{0 . 4 4 5 ^ { * }} & \mathrm{ns} & \mathrm{ns} & \mathrm{ns} & \mathrm{ns} & \mathbf{0 . 2 5 9 ^ { * }}\end{array}$

$\mathrm{Fe}(\mathrm{II})$ - ferrous iron, $\mathrm{HY}-\mathrm{Fe}$ - hydroxylamine extractable $\mathrm{Fe}, \mathrm{HCl}-\mathrm{Fe}-\mathrm{HCl}$ extractable $\mathrm{Fe}, \mathrm{GD}$ - grain density, TC - total bacterial counts, TVCan - Viable counts under anaerobic conditions. +Data obtained from Collett et al. 2007.

(bold and * indicate significant Bonferroni corrected p values at $\leq 0.004$, - indicates non-significant values). 